\title{
Vascular Anomalies (Part I): Classification and Diagnostics of Vascular Anomalies
}

\section{Gefäßanomalien (Teil I): Klassifikation und Diagnostik von Gefäßanomalien}

Authors

Maliha Sadick ${ }^{1}$, René Müller-Wille² ${ }^{2}$ Moritz Wildgruber ${ }^{3}$, Walter A. Wohlgemuth ${ }^{4}$

Affiliations

1 University Medical Center Mannhein, Institute for Clinical Radiology and Nuclear Medicine, Mannheim, Germany

2 Department for Radiology, Universitätsmedizin Göttingen, Georg-August-Universität, Göttingen, Germany

3 Department for Clinical Radiology, Universitätsklinikum Münster, Westfälische Wilhelms Universität, Münster, Germany

4 Department for Radiology, Martin-Luther-Universität Halle-Wittenberg, Halle, Germany

Key words

vascular, angiography, embolization

received 18.12 .2017

accepted 13.04.2018

Bibliography

DOI https://doi.org/10.1055/a-0620-8925

Published online: 6.6.2018

Fortschr Röntgenstr 2018; 190: 825-835

(c) Georg Thieme Verlag KG, Stuttgart · New York

ISSN 1438-9029

Correspondence

Prof. Dr. Moritz Wildgruber

Institut für Klinische Radiologie, Universitätsklinikum

Münster, Albert-Schweitzer-Campus 1,

48149 Münster, Germany

Tel.: ++49/2 51/8344381

moritz.wildgruber@ukmuenster.de

\section{ZUSAMMENFASSUNG}

Hintergrund Gefäßanomalien sind eine diagnostische und therapeutische Herausforderung. Sie erfordern dediziertes interdisziplinäres Management. Optimale Patientenversorgung hängt von einer ganzheitlichen medizinischen Begutachtung ab und erfordert ein Klassifikationssystem, erstellt von Experten in diesem Spezialgebiet, für ein fachübergreifendes Verständnis dieser komplexen Gefäßerkrankung.

Methode Ein dediziertes Klassifikationssystem nach ISSVA (International Society for the Study of Vascular Anomalies) und DiGGefA (Deutsche Interdisziplinäre Gesellschaft für Gefäßanomalien) wird vorgestellt. Das breite Spektrum der diagnostischen Modalitäten, einschließlich farbkodierter Duplexsonografie, Konventioneller Radiografie, Computertomografie mit 4D Bildgebung, MRT und auch der Katheterangiografie wird diskutiert.

Ergebnisse Kongenitale Gefäßanomalien umfassen Gefäßtumoren, die auf einer endothelialen Proliferation beruhen und vaskuläre Malformationen, basierend auf einer mesenchymalen und vaskulogenetischen Entwicklungsstörung. Gefäßtumoren verfügen über die Fähigkeit der Regression mit zunehmenden Alter des Patienten, dagegen weisen vaskuläre Malformationen einen Progress auf. Sie werden, abhängig von der dominierenden vaskulären Komponente, unterteilt in kapilläre, venöse, lymphatische, arterio-venöse und kombinierte Malformationen. Venöse Malformationen machen prozentual den größten Anteil aus (70\%), gefolgt von lymphatischen (12\%), arterio-venösen (8\%), kombinierten syndromalen (6\%) und kapillären Malformationen (4\%).

Zusammenfassung Ziel dieser Arbeit ist ein Überblick über Klassifikation und Diagnostik von kongenitalen Gefäßfehlbildungen um das interdisziplinäre Management von Gefäßanomalien zu erleichtern.

\section{Kernaussagen}

- Gefäßanomalien beinhalten Gefäßtumoren und vaskuläre Malformationen, die Seltene Erkrankungen darstellen.

- Eine angemessene Therapie beruht auf korrekter Klassifikation und Diagnose von Gefäßanomalien, basierend auf etablierten nationalen und internationalen Klassifikationssystemen, Empfehlungen und Leitlinien.

- Die Radiologie leistet einen bedeutenden Beitrag zu Klassifikation, Diagnostik und Behandlung von Gefäßanomalien.

\section{ABSTRACT}

Background Vascular anomalies are a diagnostic and therapeutic challenge. They require dedicated interdisciplinary management. Optimal patient care relies on integral medical evaluation and a classification system established by experts in the field, to provide a better understanding of these complex vascular entities.

Method A dedicated classification system according to the International Society for the Study of Vascular Anomalies (ISSVA) and the German Interdisciplinary Society of Vascular Anomalies (DiGGefA) is presented. The vast spectrum of diag- 
nostic modalities, ranging from ultrasound with color Doppler, conventional X-ray, CT with 4 D imaging and MRI as well as catheter angiography for appropriate assessment is discussed.

Results Congenital vascular anomalies are comprised of vascular tumors, based on endothelial cell proliferation and vascular malformations with underlying mesenchymal and angiogenetic disorder. Vascular tumors tend to regress with patient's age, vascular malformations increase in size and are subdivided into capillary, venous, lymphatic, arterio-venous and combined malformations, depending on their dominant vasculature. According to their appearance, venous malformations are the most common representative of vascular anomalies (70\%), followed by lymphatic malformations (12\%), arterio-venous malformations ( $8 \%$ ), combined malformation syndromes (6\%) and capillary malformations (4\%).

Conclusion The aim is to provide an overview of the current classification system and diagnostic characterization of vascular anomalies in order to facilitate interdisciplinary management of vascular anomalies.

\section{Key Points}

- Vascular anomalies are comprised of vascular tumors and vascular malformations, both considered to be rare diseases.

- Appropriate treatment depends on correct classification and diagnosis of vascular anomalies, which is based on established national and international classification systems, recommendations and guidelines.

- In the classification, diagnosis and treatment of congenital vascular anomalies, radiology plays an integral part in patient management.

\section{Citation Format}

- Sadick M, Müller-Wille R, Wildgruber M et al. Vascular Anomalies (Part I): Classification and Diagnostics of Vascular Anomalies. Fortschr Röntgenstr 2018; 190: 825835

\section{Introduction}

Even in the presence of increasing awareness of rare diseases, congenital vascular anomalies remain a diagnostic and therapeutic challenge for interventional radiologists, physicians and surgeons involved in the treatment of this entity [1]. To date, reliable data regarding the real number of affected patients in national and international treatment facilities is not available.

Congenital vascular anomalies are currently considered to be the most complex vascular disease. They include vascular tumors, characterized by increased endothelial cell proliferation, and vascular malformations with underlying mesenchymal and angiogenetic disorders [2]. Whereas vascular tumors may regress with patient's age, vascular malformations increase in size and never regress on their own [3]. They are subdivided into capillary, venous, lymphatic, arterio-venous and combined malformations, depending on their dominant involved vasculature [4]. According to their appearance, venous malformations are the most common representatives of vascular anomalies (70\%), followed by lymphatic malformations (12\%), arterio-venous malformations (8\%), combined malformation syndromes (6\%) and capillary malformations (4\%) [4].

Vascular anomalies present with diverse symptoms and morphology which makes appropriate clinical diagnosis challenging. The existing various terminologies and classification attempts have been an additional setback for standardized diagnostic and therapeutic management in the past [5]. A comprehensive and well-founded global classification system for congenital vascular anomalies, established by dedicated experts in this field, is required to allow precise diagnosis and avoid inappropriate therapeutic decisions. This applies especially to rare and multifaceted diseases involving various organs. Undoubtedly, the fundamental work on vascular anomalies and the initial classification, published by Mul- liken and Glowacki, has been a milestone in understanding the underlying disorders of vasculogenesis and angiogenesis and associated diseases [6, 7].

In 2014, the International Society for the Study of Vascular Anomalies (ISSVA) updated the existing classification and published a supplemented version with insights of vascular anomalies and causal genetic disorders of disease manifestation [8]. In Germany, the recently founded German Interdisciplinary Society for Vascular Anomalies (Deutsche interdisziplinäre Gesellschaft für Gefäßanomalien, DiGGefA) is undertaking the attempt to create further awareness and provide knowledge on the classification, diagnostic modalities and therapy of congenital vascular anomalies. It is devoted to all medical and paramedical disciplines that are involved in the diagnostic and therapeutic management of affected patients [9].

Vascular anomalies require dedicated interdisciplinary management. The aim of this review is to provide a dedicated classification system and diagnostic characterization of vascular anomalies according to the current standard of knowledge and in coherence with the internationally established ISSVA classification. This should allow all medical disciplines involved in the care of vascular anomalies to provide effective and efficient patient management. It should also facilitate an interdisciplinary approach to vascular anomalies.

\section{Classification and Diagnostic Imaging of Vascular Tumors}

Vascular anomalies are subdivided into vascular tumors and vascular malformations [4]. Vascular tumors may be subclassified as benign, locally aggressive, borderline and malignant tumors with multiple patterns of histological and clinical manifestations (for detailed 


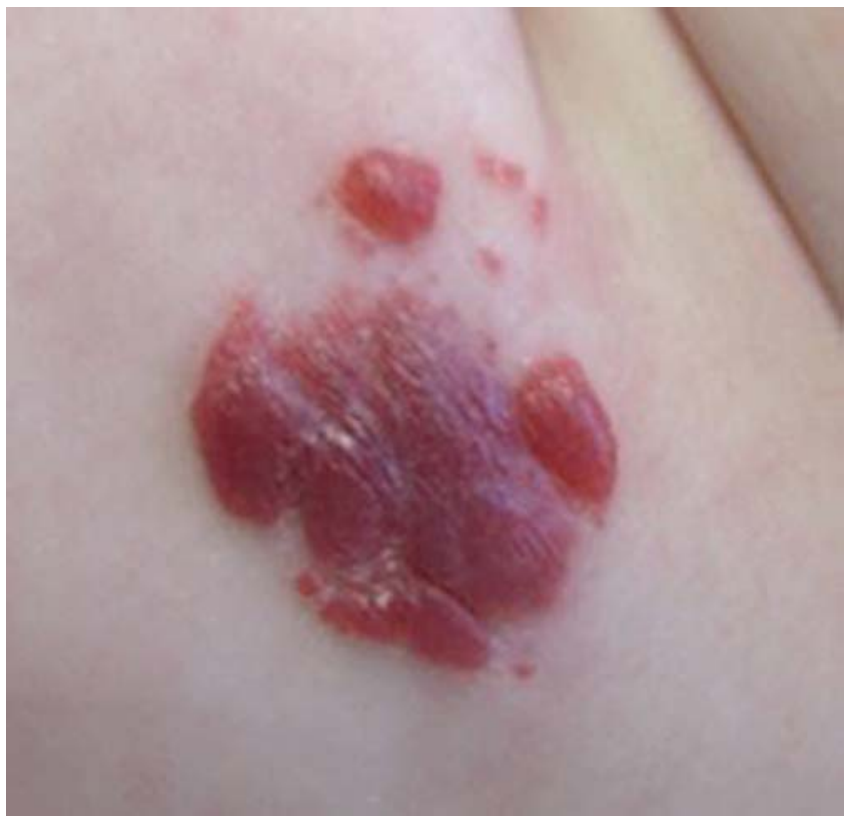

- Fig. 1 Red, rasberry-like appearance of a superficially located infantile hemangioma.

- Abb. 1 Rotes, himbeerartiges Erscheinungsbild eines oberflächlich lokalisierten infantilen Hämangioms.

description see $\boldsymbol{\nabla}$ Table 1 [8]). The most common representative of vascular tumors are hemangiomas. They are characterized by endothelial cell proliferation and angiogenesis and do not have to be present immediately after birth, but may develop in the first few weeks of life and start regressing during puberty or earlier [10]. It has to be mentioned that hemangiomas seldom regress at puberty, in general they start regressing from the 6th month of birth on. Infantile hemangiomas are much more frequent $(90 \%)$ than congenital hemangiomas (less than $2 \%$ ). Hemangiomas frequently occur in the head and neck region (70\%), followed by chest and trunk ( $25 \%$ ) and upper and lower extremities (5\%). Infantile hemangiomas tend to grow rapidly in the first few months after birth before spontaneous regression in early childhood. The characteristic appearance of an infantile hemangioma is the red, raspberry-like skin coloration, especially when located superficially ( $\triangleright$ Fig. 1 ). Hemangiomas can be small focal lesions but also extend to large multifocal tumors. They may also occur subcutaneously, in deep tissue and in organ parenchyma.

Congenital hemangiomas differ from infantile hemangiomas as they are fully developed at birth and tend to either regress rapidly (rapidly involuting congenital hemangioma, $\mathrm{RICH}$ ), regress partially (partially involuting congenital hemangioma, $\mathrm{PICH}$ ) or do not regress at all (non-involuting congenital hemangioma, $\mathrm{NICH}$ ) [11]. RICHs frequently have a pale rim around the vascular tumor accompanied by superficial telangiectasias ( $>$ Fig. 2 ).

Vascular tumors are comprised of far more entities than hemangiomas (for detailed description see $>$ Table 1, 2). Based on whether they are malignant or benign, they may require more extensive diagnostic and therapeutic evaluation than hemangiomas [8]. In this overview, the focus remains on hemangiomas, as they are the most common vascular tumor in children. Only

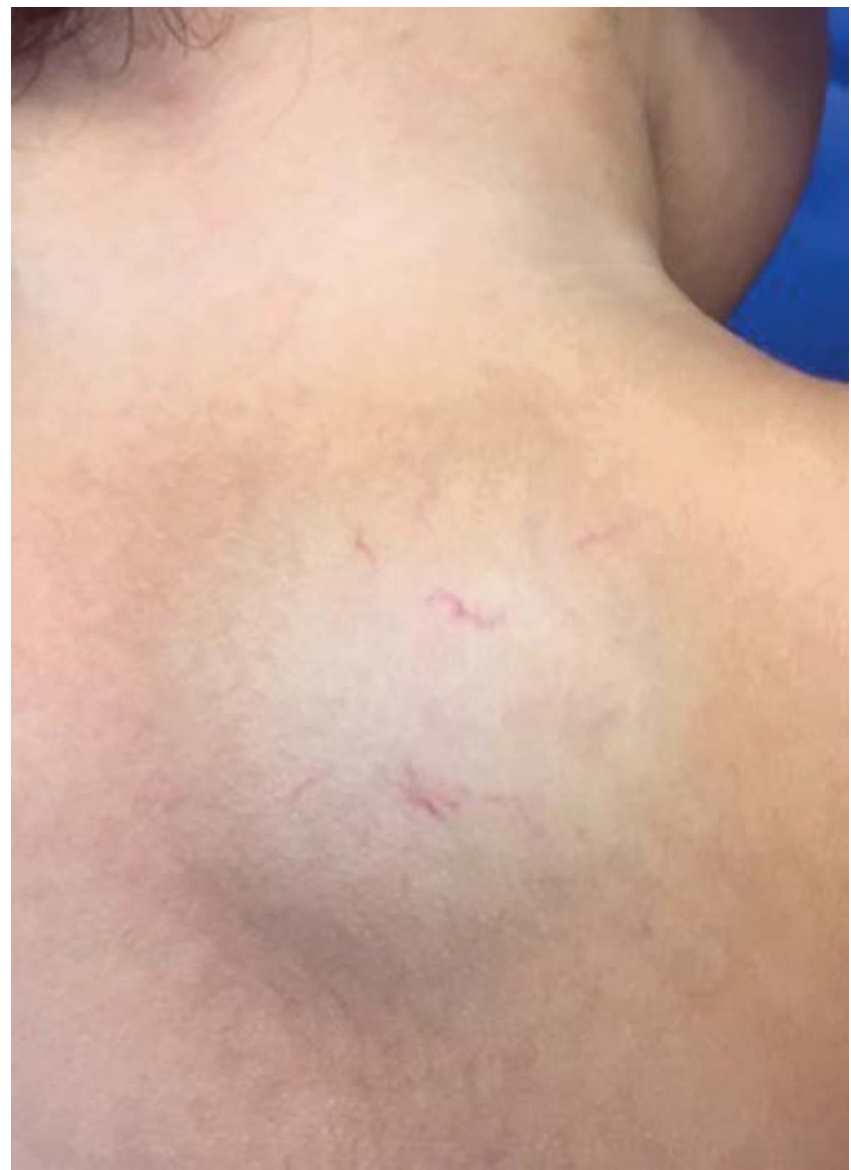

- Fig. 2 Rapidly involuting congenital hemangioma $(\mathrm{RICH})$ in the neck with superficial teleangiectasias.

- Abb. 2 Schnell involutierendes kongenitales Hämangiom (RICH) der Nackenregion mit oberflächlichen Teleangiektasien.

symptomatic hemangiomas need to be treated, in general they rarely cause symptoms that necessitate therapeutic steps. Unfortunately, not all vascular tumors in infancy regress spontaneously or decrease in size. In tumors showing continuous enlargement and clinical deterioration, potential borderline or malignant vascular tumors must always be considered [8]. Even in benign vascular tumors other than hemangiomas, like Kasabach Merritt syndrome, there is a potential risk of coagulopathy with secondary complications [8].

The immunohistochemical evidence of the glucose transporter 1 marker (Glut-1 marker) is characteristic for infantile hemangiomas and facilitates differentiation from congenital hemangiomas which do not express this cell surface protein [12].

Clinical inspection and patient history are essential for appropriate diagnosis. In general, hemangiomas represent solid, wellvascularized tumors that may present in various locations of the body with dermal, subcutaneous and parenchymal manifestation. On ultrasound with color Doppler, an echogenic mass with a fast flow pattern can commonly be observed ( $\vee$ Fig. 3a). Computed tomography (CT) hardly contributes to the diagnostic workup of vascular tumors and the associated radiation exposure can be avoided in most cases. Contrast-enhanced magnetic resonance 
- Table 1 Classification of Vascular Tumors [8].

- Tab. 1 Klassifikation von Gefäßtumoren [8].

\begin{tabular}{|l|l|} 
tumor histological entity & benign \\
\hline tumor type and subtype & $\begin{array}{l}\text { infantile hemangioma } \\
\text { congenital hemangioma } \\
\text { rapidly involuting hemangioma (RICH) } \\
\text { partly involuting hemangioma (PICH) } \\
\text { non-involuting (NICH) } \\
\text { spindle cell hemangioma } \\
\text { epitheloid cell hemangioma } \\
\text { lobular capillary hemangioma } \\
\text { tufted angioma }\end{array}$ \\
\hline
\end{tabular}

local aggressive and borderline

kaposiform hemangioendothelioma retiform hemangioendothelioma papillary intralymphatic angioendothelioma composite hemangioendothelioma kaposi sarcoma

\section{malignant}

angiosarcoma

epitheloid hemangioendothelioma
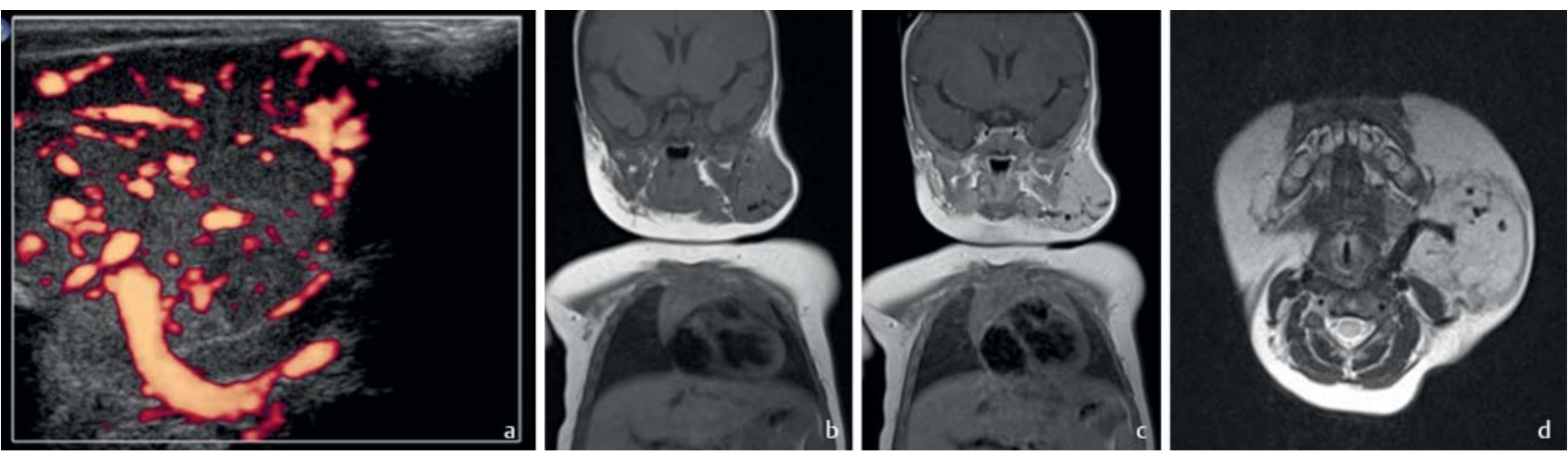

- Fig. 3 a-d Infantile hemangioma of the left parotid-masseteric region appearing as a well-vascularized echogenic lesion on color Doppler a. Hypointensity on pre-contrast coronary T1-weighted MRI b. Intensive hyperintensity on post-contrast coronary T1-weighted MRI $\mathbf{c}$ and on axial T1-weighted MRI with prominent flow voids $\mathbf{d}$.

- Abb. 3 a-d Infantiles Hämangiom der linken Parotisloge mit ausgeprägter Vaskularisation; im Farbdoppler als gefäßreicher echogener Tumor imponierend a. MRT Hypointensität in T1-Wichtung vor KM Gabe b. Ausgeprägte Hyperintensität nach KM-Gabe in der koronaren T1 gewichteten MRT $\mathbf{c}$ und charakteristische flow-voids in der axialen T1-Bildgebung $\mathbf{d}$.

imaging (MRI) provides essential information on the size and location of hemangiomas. Potential critical structures close to the hemangioma, for example in the head and neck region, with regard to compression or displacement of vessels or organs, are also effectively diagnosed.

In T1-weighted MR sequences, non-thrombosed hemangiomas appear hypointense to muscle ( $\triangleright$ Fig. 3b), with intensive hyperintensity with flow voids in post-contrast imaging due to their prominent feature of vascular perfusion, also known as "a bag of worms" ( Fig. 3c, d) [13, 14].

MRI information ( $\triangleright$ Table 3 ) is valuable and should always be considered for therapeutic decisions with regard to pharmacological, minimally invasive or surgical treatment.

\section{Classification and Diagnostic Imaging of Vascular Malformations}

Vascular malformations, based on angiogenetic and vasculogenetic dysplastic disorder, are always present at birth (even if asymptomatic) and never regress spontaneously. They may be quiescent for a long time, before mechanical or hormonal influence stimulates them to grow. With increasing size, vascular malformations can cause pain and functional impairment which require therapy. Diagnosis has to address morphology, lesion extension, dominant vessel type and potential complications regarding dermal, orthopedic, neurological and organ manifestations of the lesion. Vascular malformations can be composed of a single vessel type, combined vascular components and malformations with additional non-vascular anomalies and are therefore classified as "simple" or "combined vascular malformations" as well as "vascular malformations associated with other anomalies" (for detailed description see $>$ Table 2 [8]). 
- Table 2 Classification of Vascular Malformations [8].

- Tab.2 Klassifikation von vaskulären Malformationen [8].

simple vascular malformations

\begin{tabular}{|c|c|c|}
\hline flow component & vascular component & manifestation, syndrome \\
\hline slow flow & capillary malformation (CM) & $\begin{array}{l}\text { " CM cutaneous/mucosal ("port wine stain") } \\
\text { " CM with soft tissue and/or bone overgrowth } \\
\text { " CM with central nervous system and/or ocular anomalies (sturge-weber syndrome) } \\
\text { " CM with arterio-venous malformation (CM-AVM) } \\
\text { " teleangiectasia in hereditary hemorrhagic teleangiectasia (HHT) } \\
\text { " cutis marmorata telangiectatica congenita (CMTC) } \\
\text { " naevus simplex (stork bite, angel kiss) }\end{array}$ \\
\hline slow flow & lymphatic malformation (LM) & $\begin{array}{l}\text { - common cystic LM } \\
\text { - macrocystic LM } \\
\text { - microcystic LM } \\
\text { - mixed cystic LM } \\
\text { - generalized lymphatic anomaly (GLA) } \\
\text { - primary lymphedema } \\
\text { - LM in Gorham stout syndrome } \\
\text { - central conducting lymphatic anomaly (CCLA) }\end{array}$ \\
\hline slow flow & venous malformation (VM) & $\begin{array}{l}\text { - common VM } \\
\text { - glomovenous malformation (GVM) } \\
\text { - blue rubber bleb naevus VM syndrome } \\
\text { - cutaneo-mucosal VM (VMCM) }\end{array}$ \\
\hline fast flow & arterio-venous malformation (AVM) & $\begin{array}{l}\text { - sporadic AVM } \\
\text { - AVM in HHT }\end{array}$ \\
\hline fast flow & arterio-venous fistula (AVF) & $\begin{array}{l}\text { - sporadic AVF } \\
\text { - AVF in HHT }\end{array}$ \\
\hline \multicolumn{3}{|c|}{ combined vascular malformations } \\
\hline flow component & vascular component & manifestation, syndrome \\
\hline slow flow & $\mathrm{CM}+\mathrm{VM}$ & - capillary-venous malformation \\
\hline slow flow & $\mathrm{CM}+\mathrm{LM}$ & - capillary-lymphatic malformation \\
\hline fast flow & $C M+A V M$ & - capillary-arterio-venous malformation \\
\hline slow flow & $\mathrm{LM}+\mathrm{VM}$ & - lymphatic-venous malformation \\
\hline slow flow & $\mathrm{CM}+\mathrm{LM}+\mathrm{VM}$ & - capillary-lymphatic-venous malformation \\
\hline fast flow & $C M+L M+A V M$ & " capillary-lymphatic-arterio-venous malformation \\
\hline fast flow & $C M+V M+A V M$ & - capillary-venous-arterio-venous malformation \\
\hline fast flow & $C M+L M+V M+A V M$ & - capillary-lymphatic-venous-arterio-venous malformation \\
\hline \multicolumn{3}{|c|}{ vascular malformations associated with other anomalies } \\
\hline flow component & vascular component & manifestation, syndrome \\
\hline slow flow & $\mathrm{CM}+\mathrm{VM} \pm \mathrm{LM}$ & - with limb overgrowth (Klippel-Trénaunay syndrome) \\
\hline fast flow & $\mathrm{CM}+\mathrm{AVF}$ & - with limb overgrowth (Parkes-Weber syndrome) \\
\hline slow flow & limb VM & - with bone undergrowth (Servelle-Martorell syndrome) \\
\hline slow flow & $\operatorname{limb} C M$ & - with congenital limb hypertrophy \\
\hline slow flow & VM & - with/without spindle cell hemangioma and enchondroma (Mafucci syndrome) \\
\hline slow+fast flow & $\mathrm{LM}+\mathrm{VM}+\mathrm{CM} \pm \mathrm{AVM}$ & " with lipomatous overgrowth (CLOVES syndrome) \\
\hline slow flow & $C M+V M \pm L M$ & - with asymmetric somatic overgrowth (proteus syndrome) \\
\hline fast flow & $\mathrm{AVM}+\mathrm{VM}$ & $\begin{array}{l}\text { - with macrocephaly and lipomatous overgrowth (Bannayan-Riley-Ruvalcaba } \\
\text { syndrome; Cowden syndrome; PTEN hamartoma syndrome) }\end{array}$ \\
\hline
\end{tabular}


- Table 3 MRI diagnosis of morphology, signal intensity and flow characteristics of vascular anomalies.

- Tab.3 MR-Kriterien der Morphologie, Signalintensität und Flusscharakteristik von Gefäßanomalien.

\begin{tabular}{|c|c|c|c|c|}
\hline \multicolumn{2}{|l|}{ vascular tumor } & \multicolumn{3}{|l|}{ vascular malformation } \\
\hline & hemangioma & venous malformation & lymphatic malformation & arterio-venous malformation \\
\hline MRI morphology & solid mass & $\begin{array}{l}\text { diffuse and/or localized } \\
\text { tubular and/or nodular } \\
\text { mass }\end{array}$ & $\begin{array}{l}\text { diffuse and/or localized } \\
\text { microcysts, macrocysts or } \\
\text { combined micro- and } \\
\text { macrocysts }\end{array}$ & no mass \\
\hline \multicolumn{5}{|l|}{ MRI signal } \\
\hline T1 pre-contrast & isointense to muscle & isointense to muscle & hyperintense to muscle & isointense to muscle \\
\hline $\mathrm{T} 2$ & hyperintense to muscle & hyperintense to muscle & $\begin{array}{l}\text { intense hyperintense } \\
\text { to muscle }\end{array}$ & $\begin{array}{l}\text { tubular/nodular hyperintense flow- } \\
\text { voids }\end{array}$ \\
\hline $\begin{array}{l}\text { fat-saturated T1 } \\
\text { post-contrast }\end{array}$ & $\begin{array}{l}\text { intense hyperintense to } \\
\text { muscle and flow voids }\end{array}$ & $\begin{array}{l}\text { intense hyperintense } \\
\text { to muscle }\end{array}$ & $\begin{array}{l}\text { moderate hyperintense } \\
\text { to muscle }\end{array}$ & moderate hyperintense to muscle \\
\hline \multicolumn{5}{|c|}{ MRI flow characteristics } \\
\hline MR-angiography & fast flow & - & - & fast flow \\
\hline MR-venography & - & slow flow & - & fast flow \\
\hline
\end{tabular}

\section{Venous Malformations}

Venous malformations (VMs) are the most frequent vascular anomaly. In spite of their morphological diversity, they have multiple common diagnostic features. At clinical presentation, venous malformations are soft compressible masses with bluish skin discoloration without signs of bruit, pulsation or local redness. The skin may show tiny dark blue spots which indicate phleboliths after recurrent thrombophlebitis. Cutaneous, subcutaneous, epiand subfascial muscular or osseous manifestations of venous malformations can occur [15].

On conventional X-ray, phleboliths surrounding the venous malformation can be visible, indicating former episodes of thrombophlebitis which tend to calcify over time ( $\triangleright$ Fig. 4 ).

The flow pattern of venous malformations on ultrasound is slow flow or no flow, in case of thrombosis. They can appear as hypoechogenic clusters of compressible, dysplastic veins in every tissue layer. Depending on their venous drainage, the Puig Classification differentiates isolated type I VM without venous drainage, type II VM draining into normal veins, type III VM draining into dysplastic veins and type IV VM draining into a net of dilated veins [16].

In extensive venous malformations with potential bone involvement, MRI plays an important role for initial diagnosis and follow-up [17 - 19]. In T2-weighted imaging, VMs show a very characteristic intense hyperintense signal ( $\triangleright$ Fig.5a), they remain isointense to muscular tissue in pre-contrast T1-weighted sequences ( $\triangleright$ Fig. $\mathbf{5 b}$ ) and demonstrate hyperintensity in postcontrast T1-weighted sequences as a result of intralesional pooling of contrast agent ( $\vee$ Fig. $\mathbf{5 c}$ ) ( $\triangleright$ Table 3 ).

New generation CT scanners with ultrafast and dedicated lowdose imaging protocols must indeed be considered for pediatric examinations of vascular anomalies. Especially in the assessment of bone involvement and osseous stability in VMs, CT is very valu- able, although this indication is rather rare in VMs [20]. Examination and sedation time can be significantly reduced with this imaging modality.

Conventional percutaneous phlebography of venous malformations is usually performed prior to or during minimally invasive treatment with sclerotherapy [21].

\section{Lymphatic Malformations}

The clinical manifestation of lymphatic malformations (LMs), which are far less frequent than VMs, ranges from local swelling, red or brown skin discoloration and severe pain to generalized and recurrent infection of the affected region. Especially in the head and neck, where almost $70 \%$ of LMs occur, hemorrhage may cause swallowing disorder and discomfort. $25 \%$ of LMs are diagnosed in the chest wall and extremities and $5 \%$ in the organ parenchyma [22].

According to the cystic appearance, LMs can be macrocystic, microcystic or mixed cystic and localized or generalized at the cutaneous, subcutaneous, fatty or intramuscular level (for detailed description see $>$ Table 2 [8]). LMs can be associated with capillary malformations and other vascular anomalies. The immunohistochemical marker Podoplanin D2 - 40, representative for lymphatic endothelium, may be positive in LMs and facilitate diagnosis.

On ultrasound a no flow pattern is frequently observed. The liquid content of the thin-walled cysts is usually echofree or echopoor on ultrasound. In the case of hemorrhage into the LM or bacterial superinfection, the signal of the lymphatic content can turn from a hypoechogenic to a hyperechogenic signal.

The classic appearance of macrocystic LM on T2-weighted imaging in MRI is intense hyperintensity of the lesion with contrast uptake of the cyst walls or septae in T1-weighted sequences. 


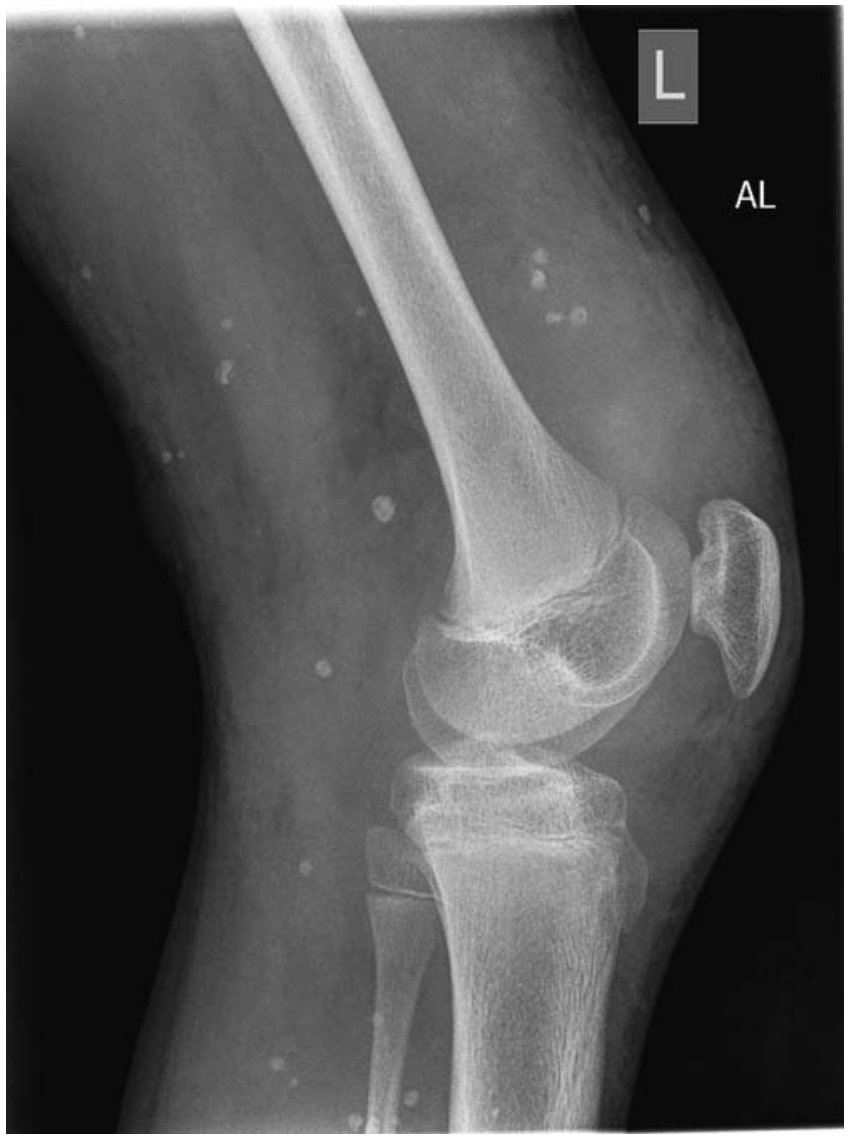

- Fig. 4 Conventional X-ray demonstrating periarticular phleboliths in the left lower extremity after several episodes of thrombophlebitis in a patient with venous malformation.

- Abb.4 Im konventionellen Röntgenbild eines Patienten imponieren periartikuläre Phlebolithen in der linken unteren Extremität nach zahlreichen Thrombophlebitiden bei venöser Malformation.

Microcystic LMs may appear as a kind of polycystic mass with contrast enhancement. However, the delineation of cystic spaces remains characteristic for LMs. MRI is the imaging modality of choice for diagnostic assessment, especially in the pretherapeutic setting ( $\triangleright$ Table 3$)$.

\section{Arterio-Venous Malformations}

Arterio-venous malformations (AVMs) are rare vascular anomalies, but undoubtedly, the most challenging to treat successfully as they invariably progress due to the fast flow in the arterio-venous connections. AVMs can cause serious clinical issues [23]. The Schobinger classification for AVMs is established and valuable for the clinical assessment of the actual condition of the vascular anomaly. It also helps in risk stratification for potential indications to treat $[24,25]$. According to Schobinger, four stages are distinguished: stage I (clinical inactive AVM, local skin hyperthermia), stage II (increase of arterio-venous shunting, presence of pulsation and bruit), stage III (destructive AVM, manifestation of ulcerations, bleeding and pain), and stage IV (decompensated AVM, heart insufficiency or cardiac failure).

AVMs are fast-flow vascular anomalies. With increasing size, it becomes more and more difficult to locate the area of direct arterio-venous shunting connections, the so-called nidus of the $\mathrm{AVM}$, and to differentiate between feeding inflow arteries and draining outflow veins. Diagnostic imaging needs to provide information on the location, extension, composition and diameter of the feeding and draining vessels, all essentials for a successful minimally invasive therapeutic approach to AVMs.

Ultrasound with color Doppler gives an impressive overview on the fast-flow arterio-venous shunts which are commonly associated with flow-related arterial, nidal and/or venous aneurysms by secondary degeneration of the dysplastic vessel wall ( $>$ Fig. 6a, b).

In complex AVMs, long examination time and a potentially extended sedation period in children and young patients has to be taken into account in MRI for comprehensive evaluation of the lesion. Flow dynamics, inflow arteries and outflow veins and the location of shunting (nidus) are best demonstrated on dynamic contrast-enhanced MR angiography and post-contrast T1-weighted isovolumetric gradient echo sequences [26]. On T2-weighted spin echo imaging, AVMs appear as hypointense tubular or nodular flow voids. Apart from this, AVMs are never accompanied by a well-defined circumscribed mass in comparison to VMs and LMs ( $\triangleright$ Table 3). Bone involvement in AVMs is best demonstrated on post-contrast T1-weighted images with intensive contrast uptake of the intraosseous vessels.

The clinical availability of time-resolved 4D-CT-angiography (4 D CTA) with low tube voltage settings has enabled a new dimension of ultrafast dynamic imaging [20]. Scanning with a wide $z$-axis field and a significant reduction of radiation dose and contrast media allow full coverage of large AVMs. Perfusion dynamics of inflow and outflow vessels can be analyzed, identification of the AVM nidus improves and accessibility for embolotherapy can be evaluated in multiple projections ( $\vee$ Fig. $\mathbf{7 a - c}$ ).

However, catheter angiography remains a prerequisite for treatment of AVMs. Transarterial, sometimes transvenous and at times also direct percutaneous access to the AVM is required to image flow dynamics, run-off vessels, draining veins and the actual nidus of the vascular anomaly [27, 28]. Usually embolization is performed in the same session.

\section{Combined Vascular Malformations and Malformations Associated with Other Anomalies}

This group of vascular anomalies is comprised of multiple combinations of slow-flow and fast-flow vascular anomalies with several distinct clinical findings, which may include skin changes, orthopedic issues and cosmetic impairment (for detailed description see $[2,8])$. Once correct diagnosis has been established, these patients often require long-term interdisciplinary clinical surveillance along with treatment of the underlying vascular involvement [29]. 

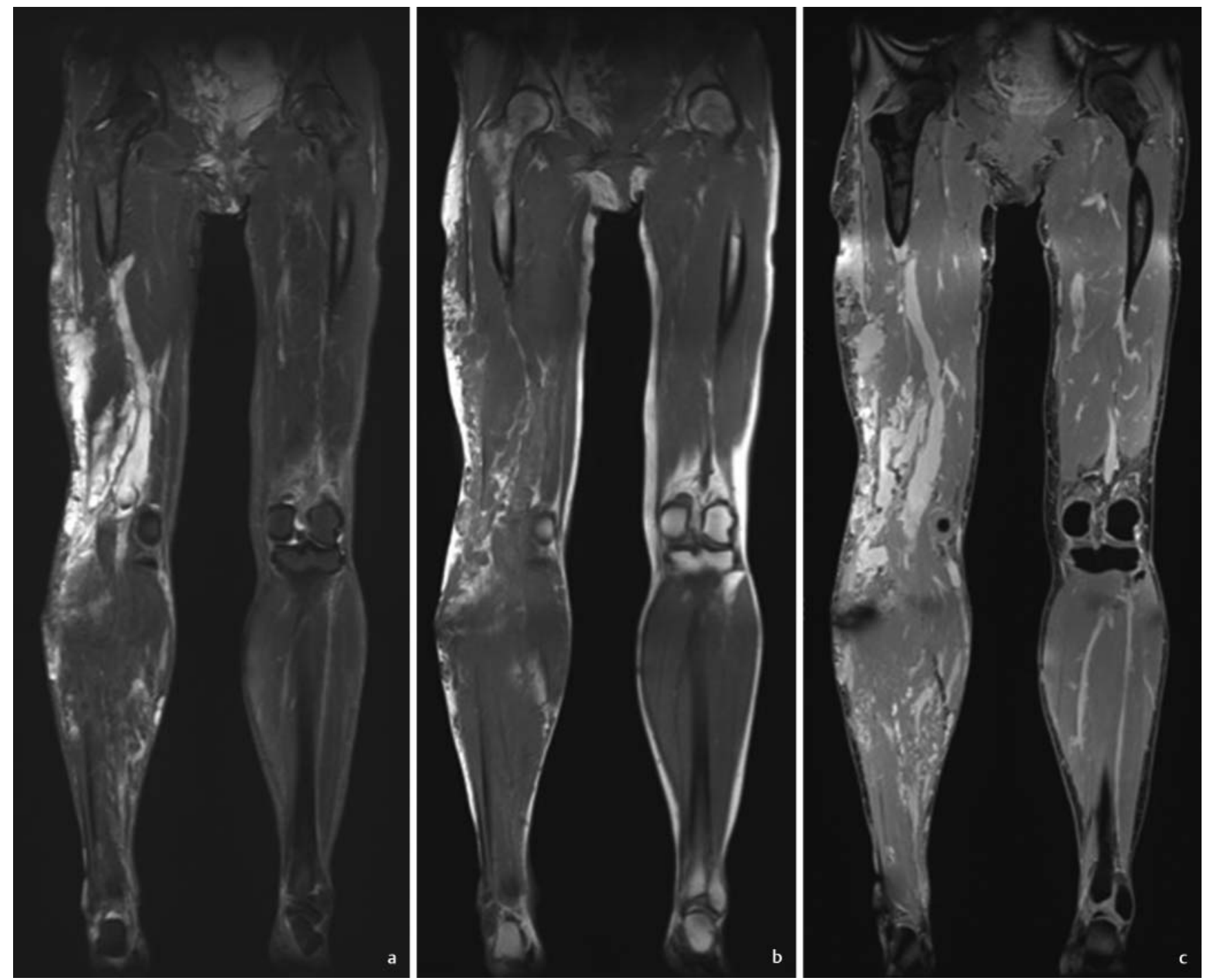

- Fig. 5 a-c Venous malformation (VM) of the right lower extremity on coronary T2-weighted MRI with marked hyperintensity along the entire thigh a. Isointense VM to muscular tissue in pre-contrast T1-weighted sequences $\mathbf{b}$. Intensive hyperintensity of the VM in post-contrast T1-weighted dynamic gradient echo c.

- Abb. 5 a-c Venöse Malformation (VM) der rechten unteren Extremität mit Signalintensität in der koronaren T2-Wichtung entlang des gesamten Oberschenkels a. Zur Muskulatur isointense VM in T1-Wichtung vor KM Gabe b. Intensive Signalintensität der VM in T1 gewichteten Gradientenechosequenzen nach KM Gabe c.

Klippel-Trénaunay Syndrome is a combination of vascular malformations (combined capillary and veno-lymphatic malformations) with tissue overgrowth of the affected extremity [8, 9]. The very frequently observed dermal "port wine staining" in the involved quadrant of the body represents capillary malformation ( $\triangleright$ Fig. 8). Patients develop recurrent painful thrombophlebitis and secondary venous insufficiency which can cause ulcerations and bleeding complications.

Gorham Stout Syndrome is a progressive lymphatic malformation with osseous involvement, also known as vanishing bone disease due to increased osteoclast activity which replaces bone with microcystic lymphatic tissue [30].
Unlike most vascular anomalies that are caused by somatic mutations, some overgrowth syndromes with complex vascular anomalies are based on germline mutations. Representatives are glomuvenous malformations with underlying autosomal dominant inheritance pattern, encoded on the glomulin gene 1p22 [31]. Affected patients suffer from painful multifocal cutaneous and subcutaneous venous keratosis ( $\triangleright$ Fig.9). Vascular anomalies based on mutations of the phosphatase and tensin homolog gen (PTEN mutations) also belong to the vascular anomalies spectrum with overgrowth syndromes (for detailed description see - Table 2 [8, 31]. Patients have to be observed at frequent intervals as PTEN-associated vascular anomalies can be associated with an increased incidence of malignancies in young patients, amongst them breast and thyroid cancer. 

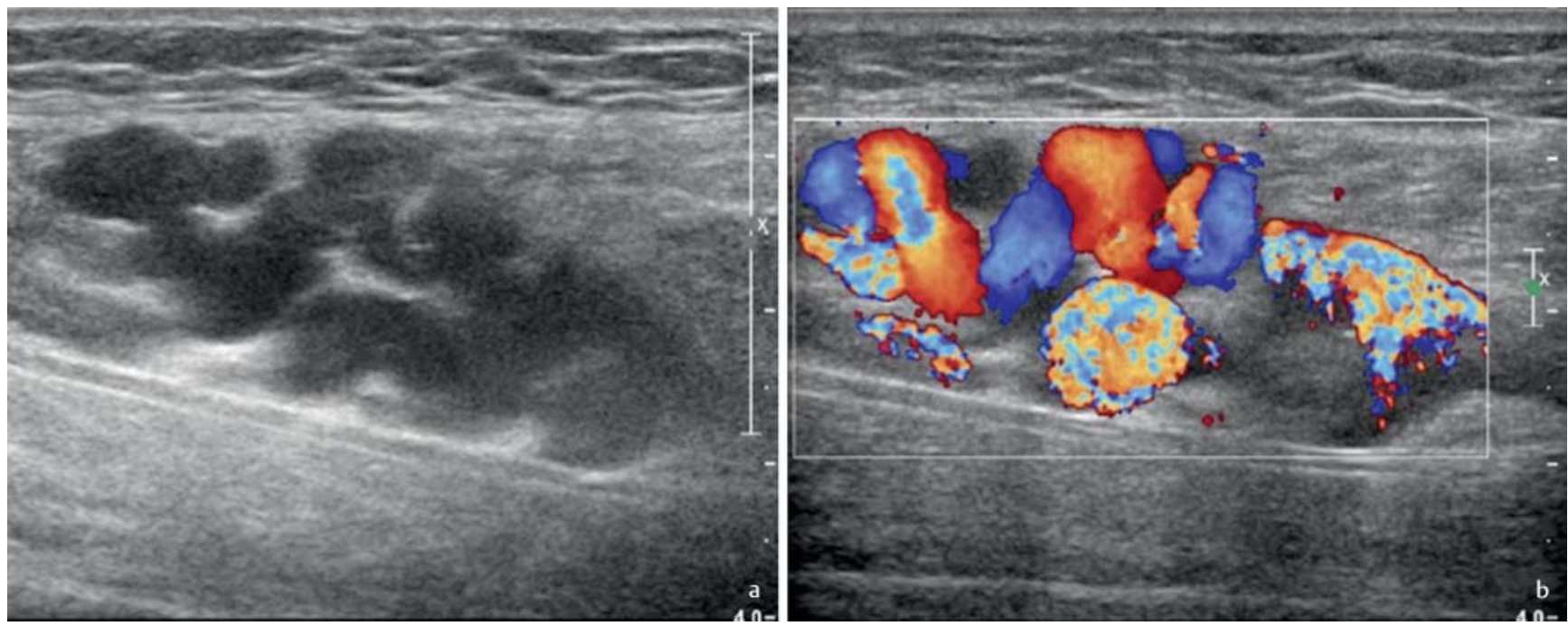

- Fig. 6 a-b Ultrasound shows ectatic and dilated intramuscular vessels of an AVM a. The massive arterio-venous shunting of the vascular anomaly in the calf is demonstrated on color Doppler $\mathbf{b}$.

- Abb. 6 a-c Ektatische und dilatierte intramuskuläre Gefäße einer AVM im Ultaschall a. Das ausgeprägte arterio-venöse Shunting der Gefäßanomalie in der Wade wird im Farbduplex ersichtlich b.
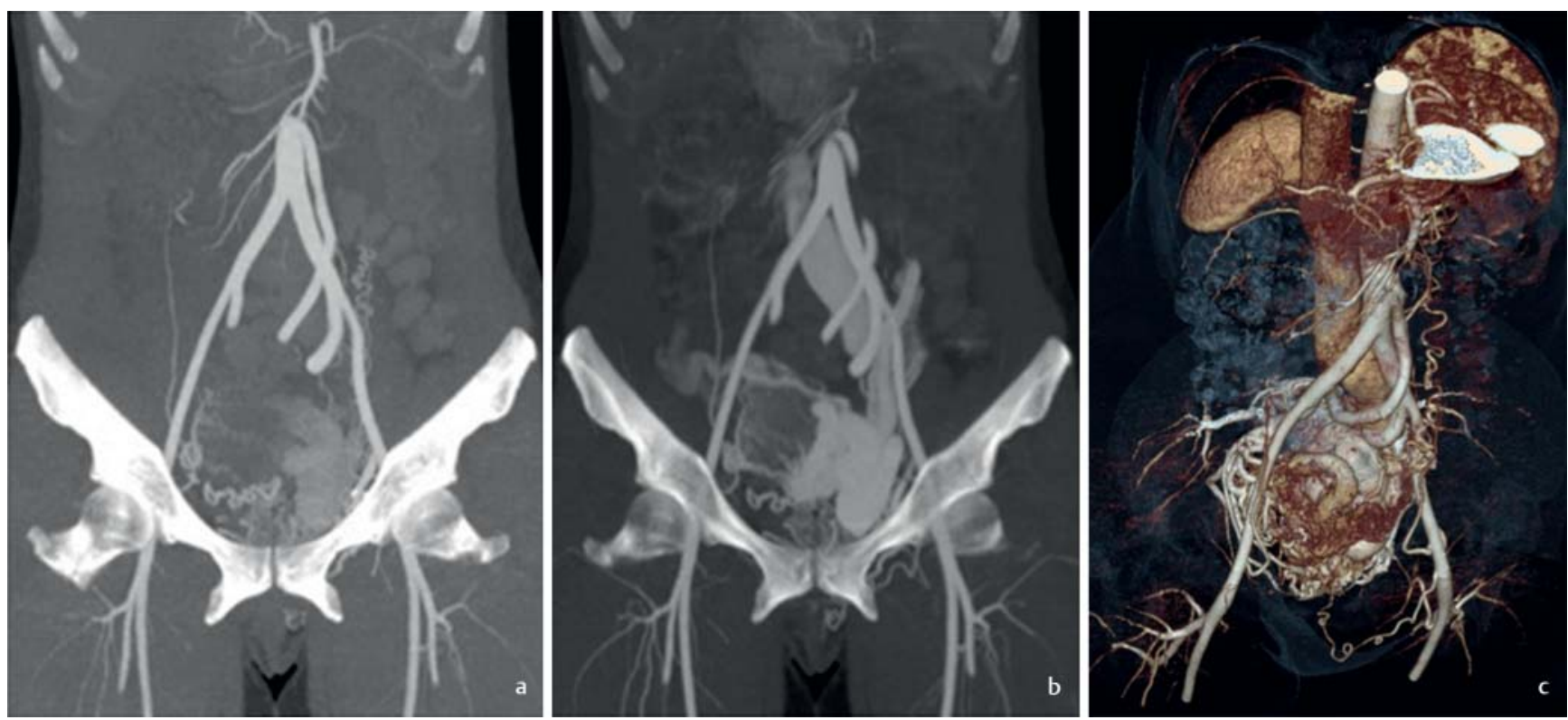

- Fig. 7 a-c Time-resolved 4D-CT-angiography (4 D CTA) of a pelvic AVM with arterio-venous shunting of iliac vessels. Perfusion dynamics of inflow and outflow vessels in arterial $\mathbf{a}$ and venous phase $\mathbf{b}$ and image reconstructions in multiple projections for identification of the AVM before embolotherapy $\mathbf{c}$.

- Abb. 7 a-c Zeitaufgelöste 4D-CT-Angiografie (4D CTA) einer pelvinen AVM mit arterio-venösen Shunts von iliacalen Gefäßen. Perfusionsdynamik von Inflow- und Outflow-Gefäßen in arterieller $\mathbf{a}$ und venöser Phase $\mathbf{b}$ und Bildrekonstruktionen in zahlreichen Projektionen zur Identifikation des Nidus der AVM vor Embolotherapie c.

As applies to other vascular anomalies, the diagnostic spectrum for combined vascular malformations and malformations associated with other anomalies ranges from ultrasound with color Doppler to CT, MRI and finally percutaneous and/or transarter- ial and transvenous access to the malformation for minimally invasive therapy. In this group of patients it is equally important not only to address the vascular anomalies but also potential clinical issues affecting patients. 


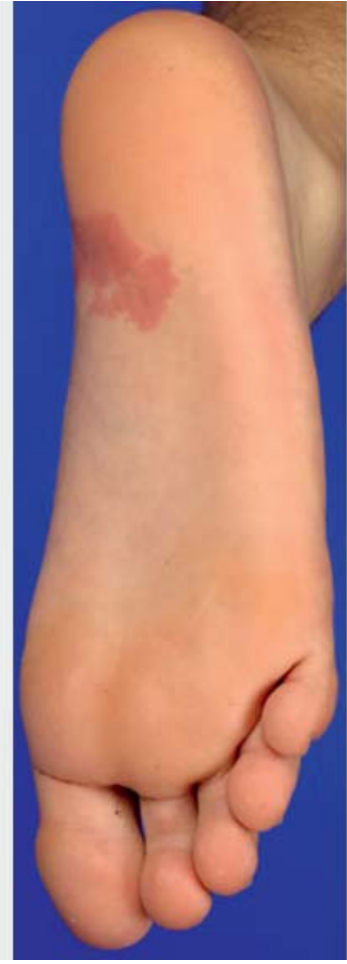

- Fig. 8 Dermal "port wine staining" (capillary malformation) in the plantar region of the foot with characteristic red appearance.

- Abb. 8 Dermales Feuermal (kapilläre Malformation) der Fußsohle mit charakteristischer rötlicher Koloration der Haut.

\section{Conclusion}

Congenital vascular anomalies are rare diseases and present a tremendous diagnostic and therapeutic challenge for the medical specialties involved in diagnosis and treatment. Delayed or missed diagnosis is observed as a result of a lack of knowledge and inappropriate terminology. Vascular tumors with the ability to regress with the patient's age and vascular malformations which increase in size and may deteriorate as the patient ages, are the two main disease categories that are summarized under vascular anomalies.

Appropriate patient management is based on early and correct diagnosis. Creating awareness of this rare disease and spreading knowledge which is easily accessible for all medical and paramedical fields that are involved in diagnostic and therapeutic patient care is the collective responsibility of vascular anomaly centers which are involved in the interdisciplinary management of patients with this complex vascular disease. Radiology as an interdisciplinary specialty with a vast spectrum of diagnostic tools and expertise in minimally invasive treatment procedures plays a key role in patient management. This review aims to present the classification and diagnostic workup of congenital vascular anomalies to facilitate access to current and emerging standards of knowledge on vascular anomalies.

\section{Conflict of Interest}

The authors declare that they have no conflict of interest.

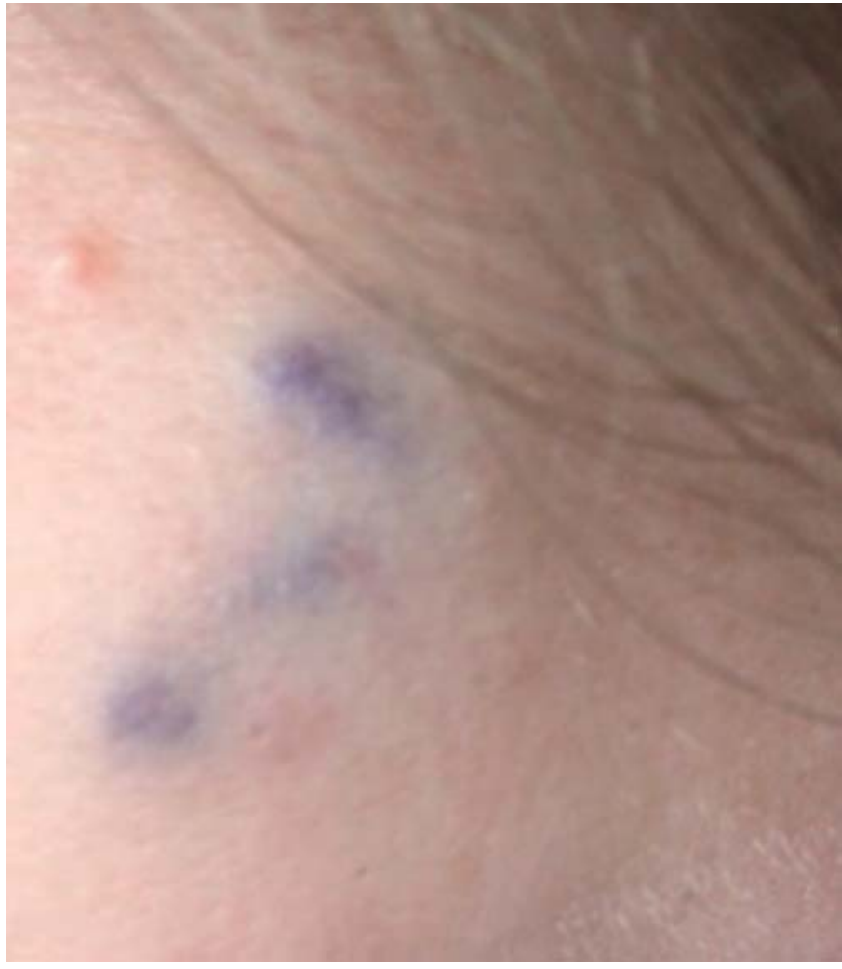

- Fig. 9 Multiple cutaneous venous keratoses in a glomuvenous malformation of the left forehead.

- Abb.9 Multiple kutane venöse Keratosen in einer glomuvenösen Malformation der linken Stirn.

Literatur

[1] Ricci KW. Advances in the Medical Management of Vascular Anomalies. Semin Intervent Radiol 2017; 34: 239-249

[2] Greene AK, Liu AS, Mulliken JB et al. Vacular Anomalies in 5621 Patients: Guidelines for Referral. J Pediatr Surg 2011; 46: 1784-1789

[3] Johnson CM, Navarro OM. Clinical and sonographic features of pediatric soft-tissue vascular anomalies part 1: classification, sonographic approach and vascular tumors. Pediatr Radiol 2017; 47: 1184-1195

[4] Adams DM, Brandão LR, Peterman CM et al. Vascular anomaly cases for the pediatric hematologist oncologists - An interdisciplinary review. Pediatr Blood Cancer 2017. doi:10.1002/pbc.2671

[5] Nosher JL, Murillo PG, Liszewski M et al. Vascular anomalies: A Pictorial Review of Nomenclature, Diagnosis and Treatment. World J Radiol 2014; 28: $677-692$

[6] Mulliken JB, Glowacki J. Hemangiomas and Vascular Malformations in Infants and Children: a classification based on endothelial characterisitics. Plast Reconstr Surg 1982; 69: 412-422

[7] Tekes A, Kalayci TO, Mitchell SE. Congenital Vascular Anomalies: Classification and Terminology. In: Mauro MA, Murphy KP, Thomson KR, (eds). Image Guided Interventions. Philadelphia: Saunders; 2013: 271-283

[8] Wassef M, Blei F, Adams D et al. Vascular Anomalies Classification: Recommendations From the International Society for the Study of Vascular Anomalies. Pediatrics 2015; 136: e203-e214

[9] http://www.diggefa.com - letzter Zugriff 14.10.2017

[10] Léaute-Labrèze C, Boccara O, Degrugillier-Chopinet C et al. Safety of Oral Propranolol for the Treatment of Infantile Hemangioma: A Systematic Review. Pediatrics 2016; 138: e20160353 
[11] Amouri M, Mesrati $\mathrm{H}$, Chaaben $\mathrm{H}$ et al. Congenital hemangioma. Cutis 2017; 99: E31 - E33

[12] Wojcicki P, Wojcicka K. Epidemiology, Diagnostics and Treatment of Vascular Tumors and Malformations. Adv Clin Exp Med 2014; 23: 475 - 484

[13] Kitami M. Diffusion-weighted imaging as a routine MRI protocol for the evaluation of infantile hemangioma. Clin Imaging 2017; pii: S08997071(17)30143-2. doi:10.1016/j.clinimag.2017.07.015

[14] Benzar I. A Diagnostic Program of Vascular Tumor and Vascular Malformations in Children According to Modern Classification. Acta Medica 2017; 60: 19-26

[15] Lee BB, Baumgartner I, Berlien P et al. Diagnosis and Treatment of Venous Malformations Consensus Document of the International Union of Phlebology (IUP): Updated 2013. International Angiology 2015; 34: 97 - 149

[16] Puig S, Aref H, Chigot V et al. Classification of venous malformations in children and implications for sclerotherapy. Pediatr Radiol 2003; 33 : 99- 103

[17] Lee JY, Suh DC. Visualization of Soft Tissue Venous Malformations of Head and Neck with 4D Flow Magnetic Resonance Imaging. Neurointervention 2017; 12: $110-115$

[18] Hung JW, Leung MW, Liu CS et al. Venous Malformation and Localized Intravascular Coagulopathy in Children. Eur J Pediatr Surg 2017; 27: $181-184$

[19] Hammer S, Uller W, Manger F et al. Time-resolved magnetic resonance angiography (MRA) at 3.0 Tesla for evaluation of hemodynamic characteristics of vascular malformations: description of distinct subgroups. Eur Radiol 2017; 27: 296 - 305

[20] Henzler T, Vogler N, Lange B et al. Low dose time-resolved CT-angiography in pediatric patients with venous malformations using 3rd generation dual-source CT: Initial experience. Eur J Radiol Open 2016; 12: $216-222$

[21] Vahlensieck M, Beltz L. The value of plain x-ray diagnosis and phlebography in the thoracic outlet syndrome. Aktuelle Radiol 1991; 1: $244-248$
[22] Smith MC, Zimmermann B, Burke DK et al. Efficacy and Safety of OK-432 Immunotherapy of Lymphatic Malformations. Laryngoscope 2009; 119 : $107-115$

[23] Weitz NA, Lauren CT, Behr GG et al. Clinical Spectrum of Capillary Malformation-Arteriovenous Malformation Syndrome Presenting to a Pediatric Dermatology Practice: A Retrospective Study. Pediatr Dermatol 2015; 32: $76-84$

[24] Clemens RK, Pfammatter T, Meier TO et al. Vascular malformations revisited. Vasa 2015; 44: 5-22

[25] Gilbert P, Dubois ], Giroux MF et al. New Treatment Approaches to Arteriovenous Malformations. Semin Intervent Radiol 2017; 34: 258 - 271

[26] MacDonald ME, Dolati P, Mitha AP et al. Flow and pressure measurements in aneurysms and arteriovenous malformations with phase contrast MR imaging. Magn Reson Imaging 2016; 34: 1322 - 1328

[27] Wohlgemuth WA, Müller-Wille R, Teusch VI et al. The Retrograde Transvenous Push-through Method: a Novel Treatment of Peripheral Arteriovenous Malformations with Dominant Venous Outflow. Cardiovasc Intervent Radiol 2015; 38: 623-631

[28] Gnannt R, Clemens RK, Pfammatter T. Transvenous Embolization of an Acquired Arteriovenous Malformation of the Arm. J Vasc Interv Radiol 2015; 26: $1585-1587$

[29] Sadick M, Dally F], Schönberg SO et al. Strategies in Interventional Radiology: Formation of an Interdisciplinary Center of Vascular Anomalies Chances and Challenges for Effective and Efficient Patient Management. Rofo 2017; 189: $957-966$

[30] Nikolaou VS, Chytas D, Korres D et al. Vanishing bone disease (GorhamStout syndrome): A review of a rare entity. World J Orthop 2014; 18: $694-698$

[31] Nguyen HL, Boon LM, Vikkula M. Vascular Anomalies Caused by Abnormal Signaling within Endothelial Cells: Targets for Novel Therapies. Semin Intervent Radiol 2017; 34: 233 - 238 